\title{
RECYKLACE STAVEBNÍHO DEMOLIČNÍHO ODPADU A JEHO VYUŽITÍ U POZEMNÍCH STAVEB
}

\section{CONSTRUCTION AND DEMOLITION WASTE RECYCLING AND USE FOR CONSTRUCTION OF BUILDINGS}

\author{
Lucie Brožová*1, Kamila Kuntová \\ ${ }^{1}$ Czech Technical University in Prague, Faculty of Civil Engineering, Thákurova 7, Praha 6, 166 29, \\ Czech Republic, lucie.brozova@fsv.cvut.cz \\ ${ }^{2}$ Czech Technical University in Prague, Faculty of Civil Engineering, Thákurova 7, Praha 6, 166 29, \\ Czech Republic, kamila.kuntova@fsv.cvut.cz
}

\begin{abstract}
Abstrakt - CZ
Příspěvek se zabývá tématikou recyklovaných stavebních materiálů a demoličním odpadem. Jsou zde uvedeny nejrozšířenější a nejzajímavější recyklované stavební materiály, jejich výroba, vlastnosti a užití. Pro lepší seznámení s jednotlivými druhy recyklovaných materiálů následuje porovnání jejich vlastností s tradičními materiály a popsání jejich výhod a nevýhod.

Klíčová slova - CZ

Recyklace, stavební materiály, životní prostředí, stavební a demoliční odpad

\section{Abstract - EN}

This paper deals with recycled building materials and demolition waste. Here are the most widely used and most interesting recycled building materials, their production, properties and use. To better understand the different types of recycled materials, comparison of their properties with traditional materials and describe their advantages and disadvantages follows.
\end{abstract}

\section{Keywords - EN}

Recycling, building materials, environment, demolition waste

\section{JEL Classification}

Q51 Valuation of Environmental Effects

Q53 Air Pollution • Water Pollution $\bullet$ Noise $\bullet$ Hazardous Waste $\bullet$ Solid Waste $\bullet$ Recycling L74 Construction

DOI: https://doi.org/10.14311/bit.2016.02.05

Editorial information: journal Business \& IT, ISSN 2570-7434, CreativeCommons license (c) () published by CTU in Prague, 2016, http://bit.fsv.cvut.cz/ 


\section{Úvod}

Žijeme $v$ době, kdy stále roste počet obyvatel a současně s ním v důsledku moderního životního stylu roste I objem odpadů. Z jakékoli produkce lidské činnosti vzniká odpad a jeho složení se $s$ rozvojem společnosti mění. Produkce odpadu v celosvětovém množství je obrovská a stále stoupá. Právě neustálý nárůst odpadu patří mezi hlavní problémy naší společnosti. Jednou z možností snížení množství odpadu a zachování čistého životního prostředí je využívání recyklovaných materiálů. $K$ této problematice se v posledních letech upírá I pozornost všech zemí EU. Hlavním cílem je všeobecné snížení množství odpadu, když však nějaký odpad vznikne, snaha je najít způsob, jak ho znovu využít bud' jako celek, nebo jako surovinu pro výrobu jiného produktu.

\section{Stavební a demoliční odpad}

Produkce stavebních a demoličních odpadů je neoddělitelně spjata jakoukoliv stavební činností a výrobou. Vznikají při různých stavebních činnostech, při výstavbě, rekonstrukcích a stavebních úpravách, při demolici a odstraňování staveb. Nejedná se pouze o budovy, ale I jiné stavby včetně cest, silnic, železnic a vodních děl. Stavební odpady a odpady z demolic jsou závažným problémem v oblasti životního prostředí, mají dopad na společnost a ekonomiku. Umístění tohoto odpadu, které je legální i nelegální, zatěžuje životní prostředí, přispívá ke zvýšení spotřeby energie a vyčerpává zdroje konečných skládek. (17) Stavebnictví je největším uživatelem přírodních materiálů a zároveň je také významným zdrojem druhotných surovin vznikajících ze stavebních a demoličních odpadů. Stavební odpad by měl být minimalizován u zdroje a pokud chceme výrazně snížit úroveň konstrukčního odpadu, měli by návrháři zvážit snižení konstrukčního odpadu během procesu navrhování. Většina stavebních odpadů vzniká z betonářského procesu. Obecně platí, že jakékoli snižení betonáže na místě vede ke snížení odpadu. Prefabrikování a prefabrikace proto nabízí významné přiležitosti pro snižení odpadu. (18) V současné době neexistují dostatečné konstrukční nástroje pro rozhodování, které by podporovaly efektivní hodnocení a implementaci minimalizace stavebních odpadů ve všech fázích návrhu. Budování informačního modelování (BIM) má potenciál pomoci architektům minimalizovat projektový odpad na jejich projektech. (19)

Z celkového množství odpadů vyprodukovaného v České republice představoval v roce 2016 stavební a demoliční odpad 39\%. (viz graf č.1)

Graf č. 1 Podíl stavebního a demoličního odpadu vyprodukovaného v ČR v roce 2016 z celkového množství odpadu.

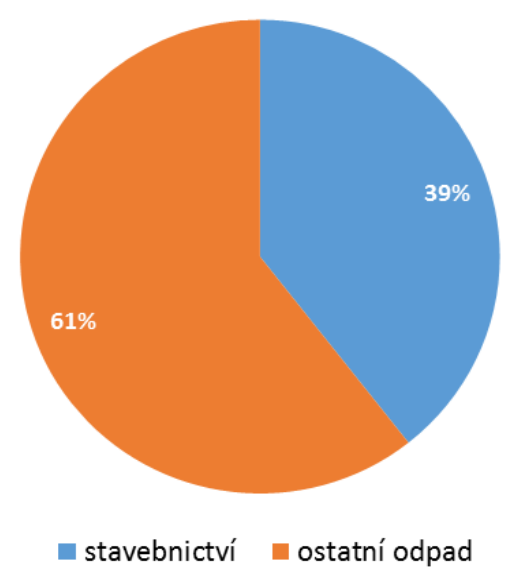

Zdroj: https://vdb.czso.cz/vdbvo2/faces/index.jsf?page=vystup-

objekt\&pvo=ZPR05\&z=T\&f=TABULKA\&katalog=30842\&str=v86 Český statistický úřad, tvorba vlastní 
V roce 2016 bylo na území České republiky vyprodukováno 10,1 mil. tun stavebního odpadu. Převážnou část z toho tvoří vytěžená zemina, která se následně využije při terénních úpravách. Zbytek tohoto stavebního odpadu se z velké většiny ukládá na skládkách, což nás řadí na chvost mezi zeměmi Evropské unie. Přitom velká část stavebního odpadu se může díky recyklaci vrátit zpět do stavebnictví jako plnohodnotný materiál. U stavebního demoličního odpadu je vyžadována maximální možná využitelnost. Stavební a demoliční odpad mǔžeme rozdělit do základních skupin podle toho, zda jsou vhodné $\mathrm{k}$ recyklaci

- Bezproblémové materiály vhodné k recyklaci

- Zemina a písky

- Kamení a štěrky z běžné těžby

- Neznečištěné betony

- Cihla

- Tašky a keramické výrobky

- Asfaltové směsi

- Štěrk ze železničního svršku, který neobsahuje nebezpečné látky

- Stavební materiály na bázi sádry

- Směsné stavební a demoliční odpady

- Problematické odpady, které obsahují nebezpečné látky a součástí jejich úpravy je oddělení a odstranění nebezpečných složek

- Cihla, její drt' a jemný prach s nebezpečnými látkami

- Sklo, plasty a dřevo s nebezpečnými látkami

- Kamení a štěrk ze železničních svršků s nebezpečnými látkami

- Okenní rámy včetně laků a nátěrů

- Asfaltové směsi obsahující dehet

- Vytěžená hlušina obsahující nebezpečné látky

- Izolační materiály, které obsahují nebezpečné látky

- Stavební a demoliční odpady obsahující rtut́

- Stavební a demoliční odpady obsahující PCB

- Jiné SOD obsahující nebezpečné látky

- Nebezpečné odpady vyloučené z recyklace

- Izolační materiál s obsahem azbestu

- Stavební materiály obsahující azbest (1)

\section{Trvale udržitelný rozvoj}

V současné době se stává stále častěji diskutovaným tématem trvale udržitelný rozvoj. Jedná se o způsob rozvoje, $v$ rámci kterého by se současná generace měla snažit zachovat životní prostředí $v$ co nejmenší změně pro generaci budoucí. Díky tomuto rozvoji by mělo docházet $k$ hospodářským a společenským pokrokům, které budou v souladu s životním prostředím. Součástí trvale udržitelného rozvoje v oblasti stavebnictví je udržitelná výstavba. (2) 
Obrázek č. 1 Principy trvale udržitelného rozvoje

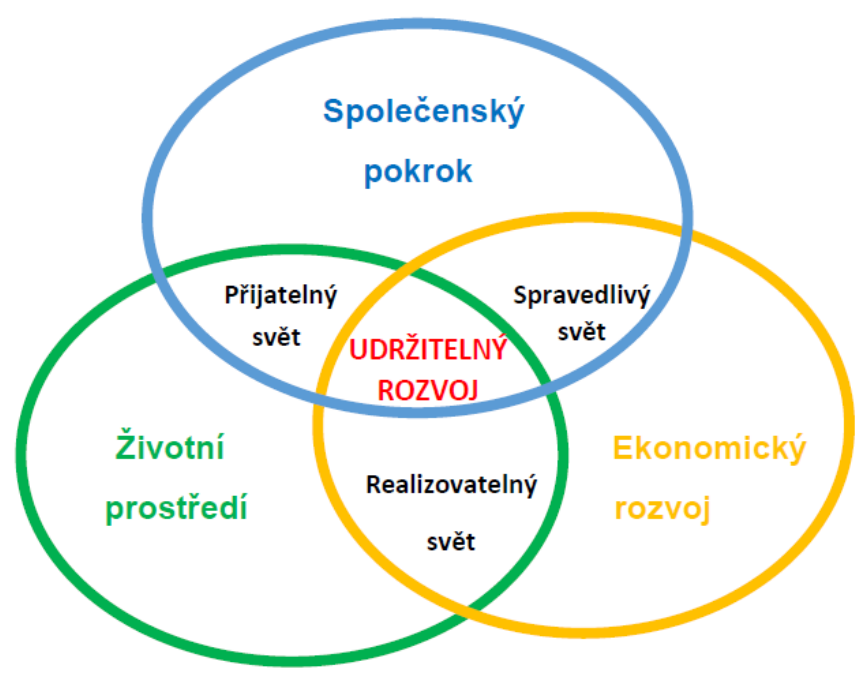

Zdroj: Vytvořeno podle http://vitejtenazemi.cz/cenia/index.php?p=trvale_udrzitelny_rozvoj\&site=spotreba, tvorba vlastní

V souvislosti s trvale udržitelnou výstavbou jsou na stavební materiály, konstrukce i stavby kladeny čím dál větší požadavky. Cíle trvale udržitelné výstavby se liší v závislosti na dané lokalitě, regionu či státu.

Mezi její hlavní cíle se řadí:

- zamezení nárůstu spotřeby energie použitím obnovitelných zdrojů,

- nahrazení neobnovitelných prírodních zdrojů recyklovanými a recyklovatelnými materiály,

- zamezení nárůstu znečištění ovzduší, snižením množství odpadu, který nelze recyklovat,

- zabránění neefektivní spotřebě pitné vody,

- efektivní využití půdy. (2)

V rámci trvale udržitelného rozvoje se na posuzování životního cyklu využívá metoda Life Cycle Assessment (dále jen LCA), která spočívá v porovnávání environmentálních dopadů produktů, hmatatelných výrobků či služeb, s ohledem na celý jejich životní cyklus.(3)

Metodu LCA Ize definovat jako shromažd'ování a vyhodnocování vstupů, výstupů a možných dopadů na životní prostředí výrobkového systému během celého životního cyklu. Je třeba proto vyhodnotit i fázi recyklace a její vliv na životní prostředí v rámci celého životního cyklu. Výstupy z konkrétní LCA studie nejsou platné obecně, ale vždy za daných a jasně specifikovaných podmínek pro konkrétní aplikaci (4).

Hodnocení životního cyklu životního prostředí (LCA) se v posledních třech desetiletích rychle rozvinulo. Dnes je LCA široce používána a používána jako nástroj pro podporu politik a regulace založené na výkonu, zejména pokud jde o bioenergii. Během uplynulého desetiletí se LCA rozšírila tak, aby zahrnovala také náklady na životní cyklus (LCC) a sociální LCA (SLCA). S tímto vývojem se LCA rozšírila z pouhého environmentálního posouzení na komplexnější hodnocení trvale udržitelného životního cyklu (LCSA). (20) 
Udržitelnost je $v$ dnešní době akceptována všemi zainteresovanými stranami jako hlavní zásada jak pro tvorbu veřejné politiky, tak pro firemní strategie. Nicméně největší výzva pro většinu organizací zůstává v reálné a zásadní implementaci koncepce udržitelnosti.(21)

\section{Recyklace}

Recyklace je definována jako znovuuvedení odpadu do cyklu a představuje nejefektivnější a zároveň nejvyužívanější způsob v České republice, jak s odpady nakládat (viz. Graf 2: Způsob nakládání s odpadem ČR). Za méně efektivní způsob zacházení s odpady Ize považovat jejich spalování a nejméně efektivním způsobem je jejich uskladnění na skládce. Recyklace umožňuje znovuvyužití odpadních materiálů jako druhotné suroviny a zároveň tím šetřit primární zdroje a životní prostředí. (5)

Graf č. 1 Způsoby nakládání s odpadem v ČR v letech 2008-2016 v tunách

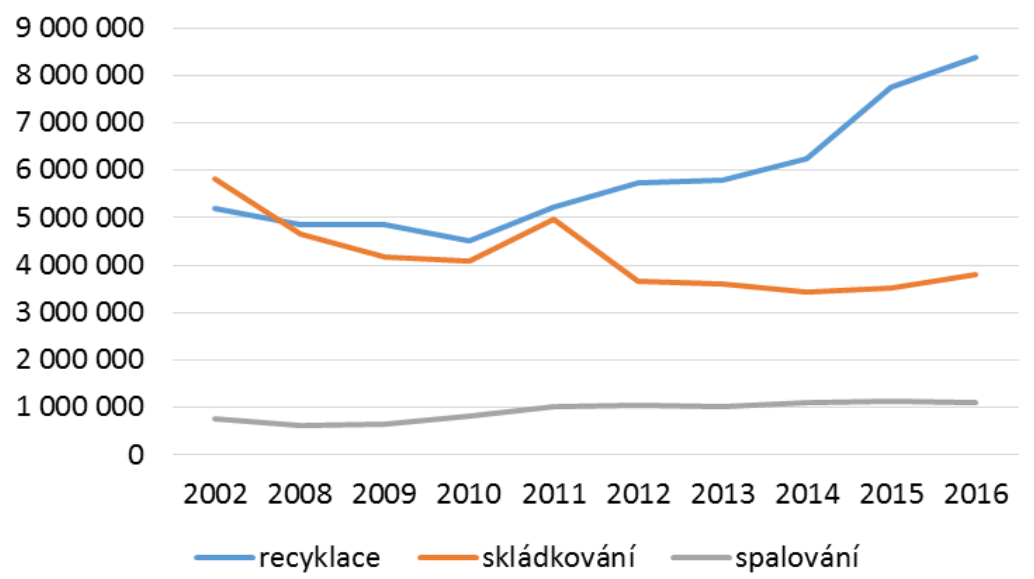

Zdroj: https://vdb.czso.cz/vdbvo2/faces/index.jsf?page=vystupobjekt\&pvo=ZPR08\&z=T\&f=TABULKA\&katalog=30842\&str=v50 Český statistický úřad, tvorba vlastní

\section{Výhody a nevýhody recyklace}

Recyklace $v$ žádném případě nepokryje veškerou spotřebu materiálů v hospodářství vyspělých zemí a ani kvalita všech recyklovaných materiálů nesplňuje požadované parametry. I přesto se recyklační průmysl nadále rozvíjí a zpracovává až 600 milionů tun druhotných surovin ročně. (5) Recyklace vede k významnému snížení emisí, spotřebě energie, potenciálu globálního oteplování a šetří místo skládek ve srovnání s likvidací odpadů na skládkách. Navíc jsou náklady na zmírnění dopadu likvidace extrémně vysoké. (17)

Mezi hlavní výhody recyklace Ize zařadit:

- ochranu životního prostředí,

- úsporu prírodních zdrojů,

- úsporu energie a pracovních sil,

- úsporu investic. 
Pro příklad sběr jedné tuny papíru ušetří životnímu prostředí až dvě tuny dřeva. Dalším př́kladem je výroba oceli, kdy u výroby jedné tuny oceli z rudy stráví zaměstnanec 80 hodin práce, oproti tomu výroba stejného množství oceli ze železného šrotu zabere až desetkrát méně času. (5)

Mezi nevýhody recyklace pak patří:

- vysoké náklady na recyklaci některých odpadů,

- neopatrné zacházení s odpady a následná manipulace s nimi vede k příměsi cizorodých látek, které negativně ovlivňují výsledné vlastnosti materiálu.

\section{Technologie recyklace stavebního a demoličního odpadu}

Technologie recyklace odpadu ze stavebnictví je velmi komplikovaný a náročný proces, v rámci kterého se stavební odpad přeměňuje na recyklát. Na kvalitu vzniklého recyklátu má velký vliv kvalita přijímaného stavebního odpadu. Proces se neobejde bez kvalitních strojů a kvalifikovaných pracovníků. (6)

Na začátku procesu pracovník ručně vytřídí materiál, který se po očištění může znovu použít. Jedná se např́klad o cihly, dlaždice, střešní tašky a podobně. Následuje oddělení materiálů jako je sklo, plast, kov a další. Proces pokračuje následným drcením a tříděním. Velké monolitické bloky, které přesahují svým rozměrem vstupní otvor drtiče, se pomocí hydraulického kladiva rozbijí na menší části a společně se zbylou sutí pokračují $k$ zásobníku drtiče. $V$ tomto zásobníku dochází $k$ rozdrcení. Díky možnosti nastavení čelistí stroje Ize určit velikost rozdrcených částic. Rozdrcené částice následně pokračují k trídícímu zařízení, kde nejprve elektromagnetický separátor zbaví drt' železných předmětů, jako jsou hřebíky a podobně. $V$ poslední části procesu je drt' roztříděna pomocí sít na různé frakce, které jsou následně pripraveny $k$ distribuci. (7)

\section{Recyklované materiály ze stavebního a demoličního odpadu}

Cihelný recyklát

Při kvalitním recyklačním procesu, Ize cihelný recyklát použít jako vstupní materiál do různých konstrukcí a prefabrikátů. Tzv. cihelná moučka se využívá $k$ výrobě antukového. $V$ současné době se nejvíce cihelný recyklát využívá jako zásypový materiál. Po nezbytných úpravách Ize tento recyklát použít i $k$ výrobě nových cihlářským stavebních dílů.

\section{Betonový recyklát}

Nejběžněji se betonový recyklát využívá jako zásypový materiál. Je využíván při zpevňovacích pracech a jako kamenivo železničních svršků. Lze ho využít $\mathrm{i}$ jako náhradu štěrkopísků v obsypech inženýrských sítí. Další využití může být jako podsypy, silnic, mostů, parkovišt', betonových konstrukcí a i jako náhražka štěrkodrtí v protipovodňových hrázích. Upravený recyklovaný beton Ize použít i jako kamenivo do nových betonů tzv. nižších tříd.

\section{Asfaltový recyklát}

Získává se odděleně od ostatních materiálů $\mathrm{v}$ podobě tzv. ker, které jsou odlamovány $\mathrm{z}$ povrchu. Zpravidla se zpracovávají na místě pomocí mobilních drtíren. Nebo se získává tzv. 
frézovaním za studena. Tento recyklát Ize využívat například při výstavbě málo vytížených cest nebo cyklostezek. Mimo to jej Ize použít i jako materiál ke stavbě protihlukových stěn.

\section{Výkopová zemina}

U výkopové zeminy se nemusí vždy jednat o odpad, většinou se použije opět k vyrovnání terénních nerovností.

\section{Recyklovaný polystyren}

Stavební průmysl je největším producentem polystyrenového odpadu. Pěnový polystyren je rozdrcen a v závislosti na stupni znečištění se s ním dále pracuje. Neznečištěný materiál lze opět použít při výrobě nových obalů či izolací. Znečištěný a jinak nevhodný polystyren je využíván $\mathrm{k}$ výrobě tzv. lehčeného betonu a izolačních omítek. Využívá se i pro vylehčení zahradního substrátu nebo při výrobě pálených cihel. Tímto způsobem je možno roztřídit a zpracovat většinu odpadního polystyrenu. Problematický je polystyren ze stavebnictví. Ten obsahuje různá aditiva a zpomalovače hoření, které recyklaci znemožňují. (8)

\section{Recyklované materiály vzniklé v jiných odvětvích využívané ve stavebnictví}

\section{Celulóza}

Celulóza patří mezi jeden z nejvíce využívaných recyklovaných stavebních materiálů. Celulózová vlákna nabízejí ekologickou variantu tepelných izolací vyrobených z minerálních či skelných vláken. Hlavní surovinou, která se využívá pro výrobu celulózy, je starý nejčastěji novinový papír. Celulózu aplikovanou foukacím zařízením Ize používat při zateplování stropů, podkroví, šikmých střech, ale i při zateplování svislých konstrukcí, například u předstěn či při zateplování fasád. (9)

\section{Pěnové sklo}

Pěnové sklo je stavební materiál s tepelně izolačními a protipožárními vlastnostmi, který se vyrábí z recyklovaného skla. Základní surovinou pro výrobu pěnového skla je odpadní obalové sklo. Pěnové sklo disponuje vysokou pevností v tlaku. Objemová hmotnost tohoto materiálu je přibližně šestkrát větší než objemová hmotnost běžného polystyrenu. Mezi největší výhody pěnového skla patří jeho nehořlavost, odolnost vůči chemickým a jiným vlivům a nenasákavost téměř pro veškeré kapaliny.

Využití pěnového skla ve formě kameniva je především jako izolační zásypy používané jak při zakládání staveb, tak i při rekonstrukcích jako zásypy do podlah.

Pěnové sklo ve formě bloků se používá jako tepelná izolace střech, podlah a stěn. Jelikož je pěnové sklo velmi mechanicky odolné, Ize ho používat i na střechy pochozí a pojízdné.(9)

\section{Sádrovláknité desky Fermacell}

Sádrovláknité desky se podobají sádrokartonu, ale na rozdíl od sádrokartonu, který se skládá ze sádrové desky a z obou stran chránícím kartonem, je u sádrovláknitých desek sádrová deska vyztužená celulózovými vlákny. Sádrovláknité desky Fermacell mají několik možností využití, kdy nejčastěji nahrazují sádrokartonové desky. Jejich vlastnosti jim umožňují použití v konstrukcích, na které jsou kladeny vysoké požadavky na mechanickou odolnost povrchu, únosnost, požární odolnost či akustickou izolaci. Díky jejich naimpregnování je Ize aplikovat i do vlhkých prostor.

Desky a panely z tetrapaku 
Hlavní surovinou pro výrobu desek a panelů z tetrapaku jsou použité vrstvené obaly skládající se z vrstvy papíru, polyetylenu a hliníkové folie. Tyto obaly pocházejí jak z komunálního odpadu, tak i z technologického odpadu, který vzniká při výrobě vrstvených papírových kartonů. Desky z tetrapaku zevnějškem připomínají sádrokarton, ale jejich vlastnosti jsou nejen sádrokartonu konkurenceschopné, ale v některých oblastech dokonce lepší. Desky jsou klasifikovány jako obtižně hořlavé. Také disponují nízkou nasákavostí a prezentují se vynikající pevností a pružností. Nejčastěji se desky využívají jako obkladový materiál, který se může aplikovat uvnitř i vně stavby, kde bude následně deska opatřena omítkou či obkladem. Dále Ize tyto desky využívat jako ztracené bednění, např́klad při betonáži svislých konstrukcí.(11)

\section{Střešní krytina z recyklovaného plastu}

Střešní krytiny vyráběné z recyklovaného materiálu nejsou v České republice tak rozšířené. Nabízejí však jednu z možností, jak nahradit už tradiční břidlice nebo šindele. Recyklovaná střešní krytina se vyrábí z odpadního plastu. Tento plast má původ především $v$ automobilovém průmyslu či u kabelových izolantů. Tato krytina má velmi malou hmotnost, vysokou pevnost, snadnou tvarovatelnost, nenasákavost a dlouhou životnost.(12)

\section{Recyklovaná džínovina}

V České republice je recyklovaná džínovina nejméně známý a používaný recyklovaný materiál ve stavebnictví. Zhotovení recyklované džínoviny je časově i energeticky nenáročné. Hlavní surovina pro výrobu tohoto materiálu jsou vlákna bavlny. Tato vlákna jsou získávána ze zbytků textilu. Recyklovaná džínovina má výborné tepelně a zvukově izolační vlastnosti. Tento materiál se může využívat pro zateplování vodorovných konstrukcí, jako stropů a střech, či pro zateplení svislých konstrukcí, napríklad příček.

Foukaná izolace ze skelných vláken

Popularita foukaných izolací v naší republice stále roste. Přispívají k tomu zvyšující se energetické požadavky na zateplení budov i snadnost její aplikace. Dalším kladem těchto izolací je, že jsou spotřebovávány beze zbytku. Mimo již zmíněnou foukanou izolaci z celulózy stojí jistě za pozornost $\mathrm{i}$ foukaná izolace ze skelných vláken. Hlavní složkou této izolace je recyklované sklo. Základní surovinou pro výrobu foukané izolace ze skelných vláken je recyklované sklo, popř́ípadě skelná vlna.

\section{Porovnání vlastností recyklovaných materiálů s materiály tradičními}

Mezi základní parametry sloužící k porovnání stavebních materiálů patří následující měřítka:

- cena - Cenou je vyjádřena peněžní hodnota materiálu.

- součinitel tepelné vodivosti $\lambda$ - Tento součinitel vystihuje schopnost materiálu vést teplo. Čím je tato hodnota menší, tím se zlepšují tepelně izolační vlastnosti materiálu. (13)

- měrná tepelná kapacita c - Měrná tepelná kapacita vyjadřuje teplo potřebné $\mathrm{k}$ ohřátí jedné jednotky hmotnosti dané látky v kilogramech o jeden stupeň Celsia. (13)

- faktor difuzního odporu $\mu$ - Tento parametr určuje, kolikrát je lepší propustnost vodní páry nehybnou vrstvou vzduchu oproti propustnosti stejnou tloušt́kou dané látky. Čím je hodnota tohoto faktoru vyšší, tím narůstá odpor materiálu vůči propustnosti vodní páry. (14)

- ekologicky šetrný materiál - Rozumí se tím, že materiál je nezávadný k životnímu prostředí a popř́ípadě se dá i po skončení životnosti recyklovat. (15) 
- životnost - Jedná se o průměrnou dobu, po kterou stavební materiál splňuje svưj úkol v rámci stanovených provozních podmínek a jeho opotřebení je v rámci předepsané tolerance. (16)

- třída reakce na oheň - Tento parametr udává, jak daný materiál přispívá k šíření ohně, neboli jakou rychlostí materiál hoří. Rozlišuje se sedm základních skupin. (13)

- mrazuvzdornost - Mrazuvzdornost představuje odolnost materiálu vůči mrazu. Základní jednotkou mrazuvzdornosti je cyklus. Během jednoho cyklu dochází $k$ nasycení materiálu vodou, zmrazení z hodnoty $20^{\circ} \mathrm{C}$ na $-20^{\circ} \mathrm{C}$ a následnému zahřátí zpět na původní teplotu. (9)

Vzhledem k rozsáhlosti dané problematiky a množství materiálů byly pro porovnání vybrány jen některé zajímavé materiály. 
Schéma č. 1 Recyklované a tradiční stavební materiály

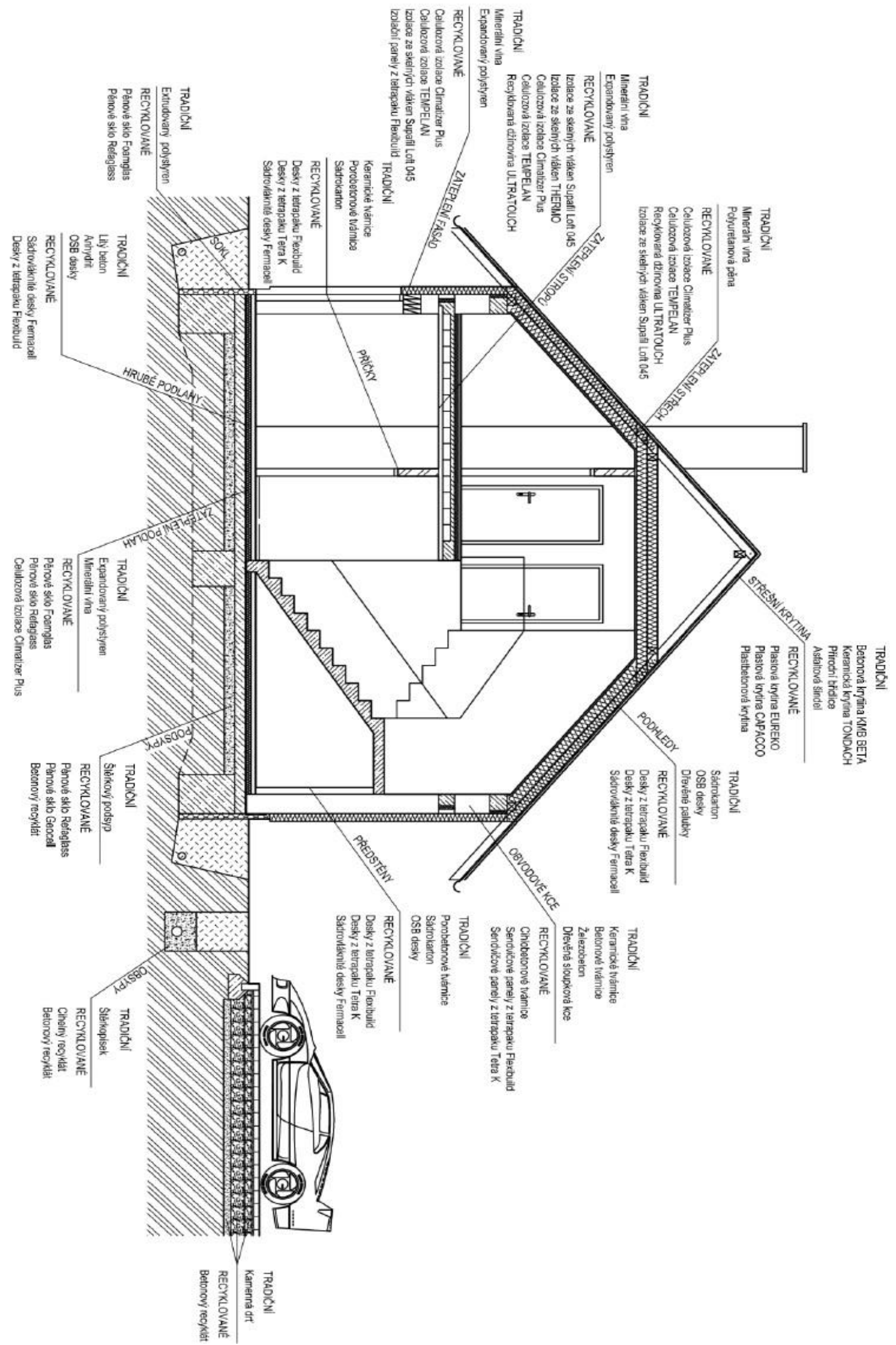

Zdroj: Vlastní tvorba 


\section{Podsypy základových konstrukcí}

Do porovnání byly nejprve vybrány materiály využívané jako podsypy při zakládání staveb. Jako zástupce tradičního materiálu byl zvolen štěrkový podsyp, z recyklovaného materiálu pak štěrk z pěnového skla.

Obrázek č. 2 Porovnání podsypů základových konstrukcí

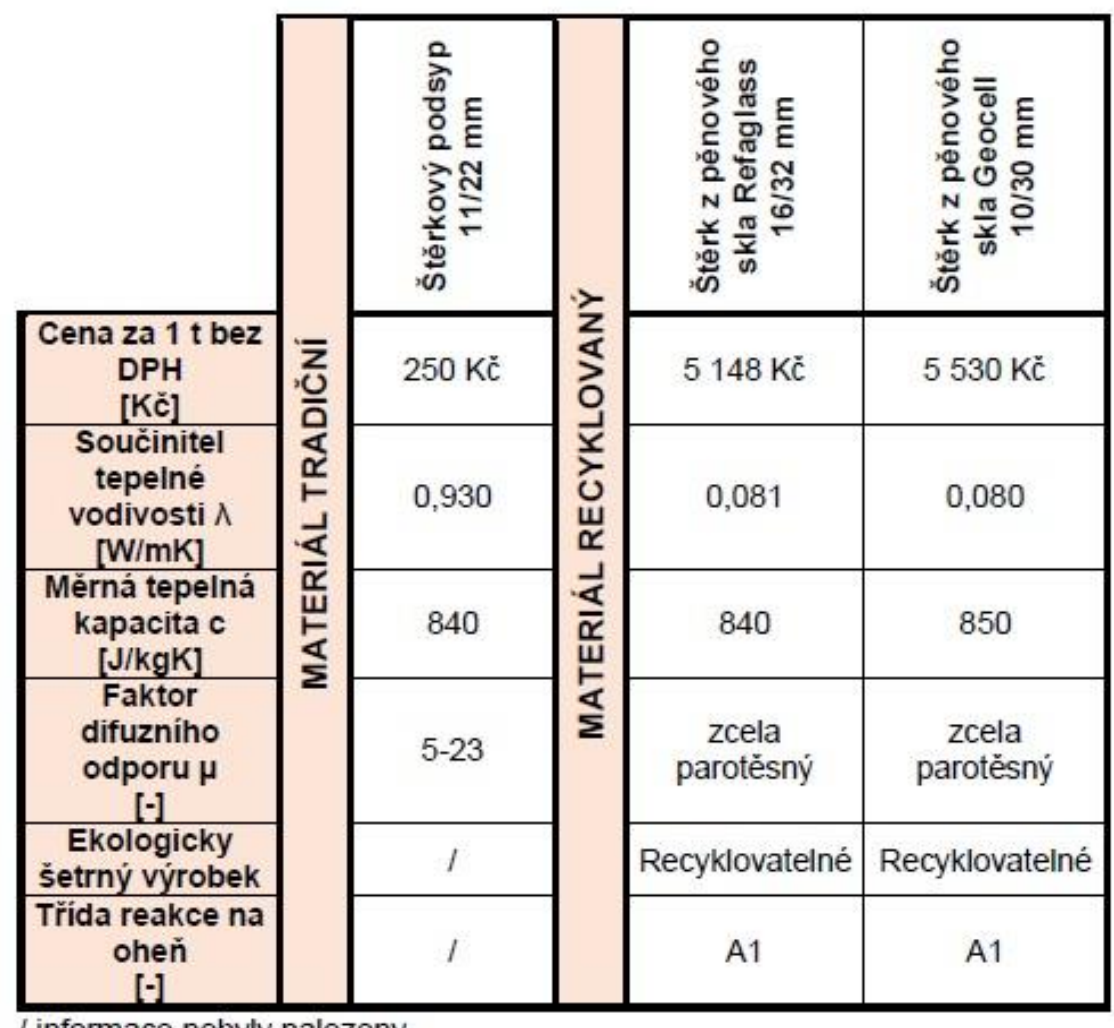

/ informace nebyly nalezeny

Zdroj: Vlastní tvorba

Při tomto porovnání byly zjištěny výhody a nevýhody štěrku z pěnového skla:

Výhody:

- Výborné tepelně izolační vlastnosti

- Nenasákavost

- $100 \%$ recyklovatelné

- Nehořlavý

- Vysoká pevnost v tlaku

Nevýhody:

- Cena materiálu

\section{Obvodové konstrukce}

Možností nahrazení tradičních materiálů za recyklované v obvodových konstrukcích není mnoho. Za jednu z nich lze považovat cihlobetonové tvárnice či sendvičové panely z tetrapaku. Hlavním 
problémem při hledání informací o těchto materiálech bylo jejich nedostatečné množství uváděné výrobci.

Obrázek č. 3 Porovnání obvodových konstrukcí

\begin{tabular}{|c|c|c|c|c|c|c|c|c|}
\hline & \multirow{9}{*}{ 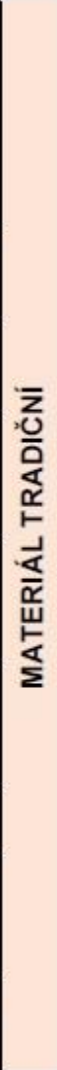 } & 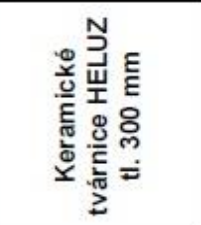 & 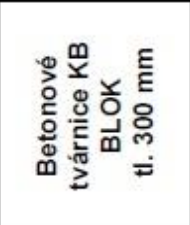 & 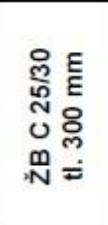 & \multirow{9}{*}{ 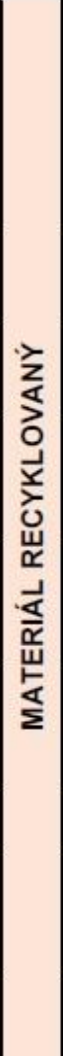 } & 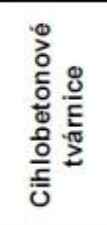 & 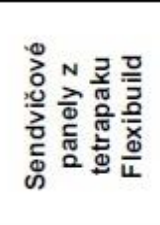 & 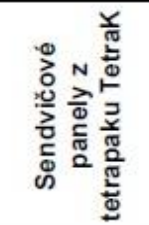 \\
\hline $\begin{array}{c}\text { Cena za } 1 \mathrm{~m}^{2} \\
\text { bez DPH } \\
\text { [Kč] }\end{array}$ & & $688 \mathrm{Kc \check {C }}$ & $1104 \mathrm{Kč}$ & 1 & & 1 & 1 & $554 \mathrm{Kčc} *$ \\
\hline $\begin{array}{c}\text { Objemová } \\
\text { hmotnost } \\
{\left[\mathrm{kg} / \mathrm{m}^{3}\right]}\end{array}$ & & 670 & 1150 & 2500 & & 1600 & I & 580 \\
\hline $\begin{array}{c}\text { Součinitel } \\
\text { tepeiné } \\
\text { vodivosti } \wedge \\
{[\mathrm{W} / \mathrm{mK}]}\end{array}$ & & 0,093 & 1,300 & 1,580 & & 0,690 & 0,053 & 0,050 \\
\hline $\begin{array}{c}\text { Měrná } \\
\text { tepelná } \\
\text { kapacita c } \\
{[\mathrm{J} / \mathrm{kgK}]}\end{array}$ & & 1000 & 1020 & 1020 & & 840 & 1 & I \\
\hline $\begin{array}{c}\text { Faktor } \\
\text { difuzniho } \\
\text { odporu } \mu \\
{[-]}\end{array}$ & & 5 & 1 & 32 & & 8 & 320 & 375 \\
\hline $\begin{array}{c}\text { Životnost } \\
\text { [rok] }\end{array}$ & & $80-150$ & $60-80$ & $60-80$ & & I & 80 & 80 \\
\hline $\begin{array}{c}\text { Ekologicky } \\
\text { šetrný } \\
\text { výrobek }\end{array}$ & & $\begin{array}{l}\text { ANO, Z } \\
\text { príirodnich } \\
\text { surovin } \\
\text { recyklovatelné }\end{array}$ & Recyklovatelné & 1 & & ANO & $\begin{array}{c}\mathrm{Ne}, \\
\text { polystyren } \\
\text { vyroben } \\
\mathrm{z} \text { ropy } \\
\end{array}$ & $\begin{array}{c}\mathrm{Ne}, \\
\text { polystyren } \\
\text { vyroben z } \\
\text { ropy }\end{array}$ \\
\hline $\begin{array}{c}\text { Třida reakce } \\
\text { na oheň } \\
{[-]}\end{array}$ & & A1 & $\mathrm{A} 1$ & $\mathrm{~A} 1$ & & 1 & 1 & c \\
\hline
\end{tabular}

Výsledkem srovnání výše uvedených materiálů je zjištění těchto výhod a nevýhod recyklovaných obvodových konstrukcí z tetrapaku:

Výhody:

- Cena materiálu

- Lepší tepelně izolační vlastnosti

- Rychlost výstavby

Nevýhody:

- Přispívá ke vzniku požáru

- Menší odolnost vưči mechanickému poškození

\section{Zateplení střech, stropů, stěn}

U tepelných izolací byly nejprve porovnávány izolační materiály šikmých střech (viz. Obrázek 4: Porovnání zateplení šikmých střech), následně materiály používané k zateplení stropů (viz. Obrázek 5: Porovnání zateplení stropů), dále k zateplení podlah (viz Obrázek 6: Porovnání zateplení podlah) a nakonec izolační materiály stěn (viz. Obrázek 7: Zateplení fasády). Recyklované tepelné izolace jako 
celulóza, recyklovaná džínovina, izolace ze skelných vláken či desky z pěnového skla byly porovnávány s klasickými materiály, minerální vatou a expandovaným polystyrenem.

Obrázek č. 4 Porovnání zateplení šikmých střech

\begin{tabular}{|c|c|c|c|c|c|c|c|c|}
\hline & \multirow{5}{*}{ 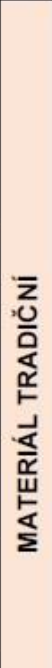 } & 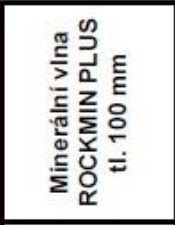 & 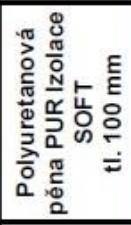 & \multirow{7}{*}{ 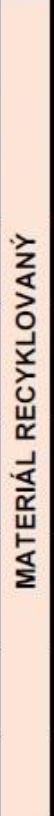 } & 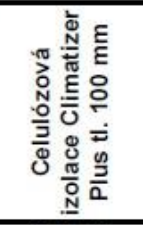 & 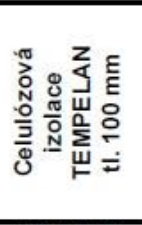 & 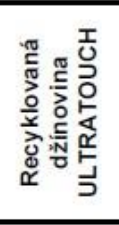 & 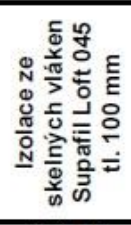 \\
\hline $\begin{array}{c}\text { Cena za } 1 \\
\mathrm{~m}^{2} \text { bez DPH } \\
\text { [Kč] }\end{array}$ & & $86 \mathrm{Kc}$ & $270 \mathrm{Kc \check {c }}$ & & $\begin{array}{c}133 \mathrm{Kć} \\
\text { vč. } \\
\text { zafoukání }\end{array}$ & $\begin{array}{c}86-95 \mathrm{Kč} \\
\text { vč. } \\
\text { zafoukáni }\end{array}$ & $467^{\star} K \check{c}$ & $\begin{array}{c}120 \mathrm{Kčc} \\
\text { vč. } \\
\text { zafoukáni }\end{array}$ \\
\hline $\begin{array}{c}\text { Součinitel } \\
\text { tepelné } \\
\text { vodivosti } \Lambda \\
\text { [W/mK] }\end{array}$ & & 0,037 & 0,035 & & $\begin{array}{c}0,035- \\
0,042\end{array}$ & $\begin{array}{c}0,037- \\
0,040\end{array}$ & 0,037 & $\begin{array}{c}0,034- \\
0,045\end{array}$ \\
\hline $\begin{array}{c}\text { Mèrná } \\
\text { tepelná } \\
\text { kapacita c } \\
{[\mathrm{J} / \mathrm{kgK}]}\end{array}$ & & 840 & 800 & & 1907 & 2000 & 1 & 840 \\
\hline $\begin{array}{c}\text { Faktor } \\
\text { difuzniho } \\
\text { odporu } \mu \\
{[-]}\end{array}$ & & 1 & 3,5 & & $1,1-3$ & 1,5 & 1 & 1 \\
\hline $\begin{array}{c}\text { Ekologicky } \\
\text { šetrný } \\
\text { výrobek }\end{array}$ & & $\begin{array}{c}\mathrm{Ne} \text {, obsah } \\
\text { formaldehydu }\end{array}$ & I & & ANO & ANO & ANO & ANO \\
\hline $\begin{array}{c}\text { Tríida reakce } \\
\text { na oheñ } \\
{[-]}\end{array}$ & & A1 & E & & C & B & A1 & A1 \\
\hline
\end{tabular}

Obrázek č. 5 Porovnání zateplení stropů

\begin{tabular}{|c|c|c|c|c|c|c|c|c|c|}
\hline & \multirow{7}{*}{ 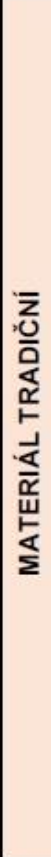 } & 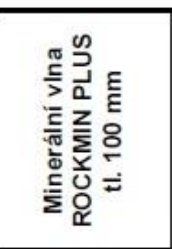 & 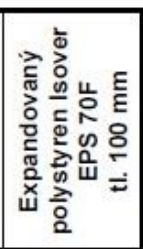 & \multirow{7}{*}{ 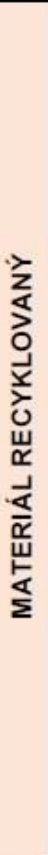 } & 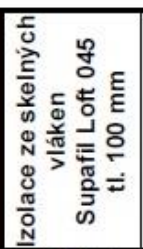 & 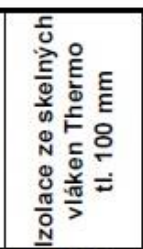 & 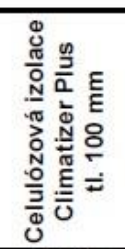 & 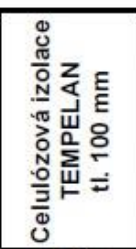 & 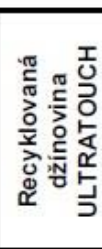 \\
\hline \multirow{2}{*}{$\begin{array}{c}\text { Cena za } 1 \mathrm{~m}^{2} \\
\text { bez DPH } \\
{[\mathrm{Kč}]} \\
\text { Součinitel } \\
\text { tepelné } \\
\text { vodivost } \Lambda \\
{[\mathrm{W} / \mathrm{mK}]} \\
\end{array}$} & & $71 \mathrm{Kc}$ & $125 \mathrm{Kc \check {c }}$ & & $\begin{array}{c}109 \mathrm{Kć} \\
\text { vč. } \\
\text { zafoukáni }\end{array}$ & $\begin{array}{c}123 \mathrm{Kć} \\
\text { vč. } \\
\text { zafoukáni }\end{array}$ & $\begin{array}{c}109 \mathrm{Kc} \\
\text { vč. } \\
\text { zafoukáni }\end{array}$ & \begin{tabular}{|c|}
$67 \mathrm{Kć}$ \\
vć. \\
zafoukáni \\
\end{tabular} & 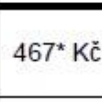 \\
\hline & & 0,037 & 0,039 & & $\begin{array}{c}0,034- \\
0,045\end{array}$ & 0,040 & $\begin{array}{c}0,035- \\
0,042\end{array}$ & $\begin{array}{c}0,037- \\
0,040\end{array}$ & 0,037 \\
\hline \multirow{4}{*}{$\begin{array}{c}\text { Mërná } \\
\text { tepelná } \\
\text { kapacita c } \\
\text { [J/kgK] } \\
\text { Faktor } \\
\text { difuzniho } \\
\text { odporu } \mu \\
{[-]} \\
\text { Ekologicky } \\
\text { šetrný } \\
\text { výrobek } \\
\text { Tř́da reakce } \\
\text { na oheñ } \\
{[-]}\end{array}$} & & 840 & 1270 & & 840 & 1 & 1907 & 2000 & I \\
\hline & & 1 & $20-40$ & & 1 & 1 & $1,1-3$ & 1,5 & I \\
\hline & & $\begin{array}{c}\mathrm{Ne} \text {, obsah } \\
\text { formaldehydu }\end{array}$ & $\begin{array}{c}\mathrm{Ne}, \\
\begin{array}{c}\text { vyroben z } \\
\text { ropy }\end{array} \\
\end{array}$ & & ANO & ANO & ANO & ANO & ANO \\
\hline & & A1 & E & & A1 & A1 & C & B & $\mathrm{A} 1$ \\
\hline
\end{tabular}

Zdroj: Vlastní tvorba 
Obrázek č. 6 Porovnání zateplení podlah

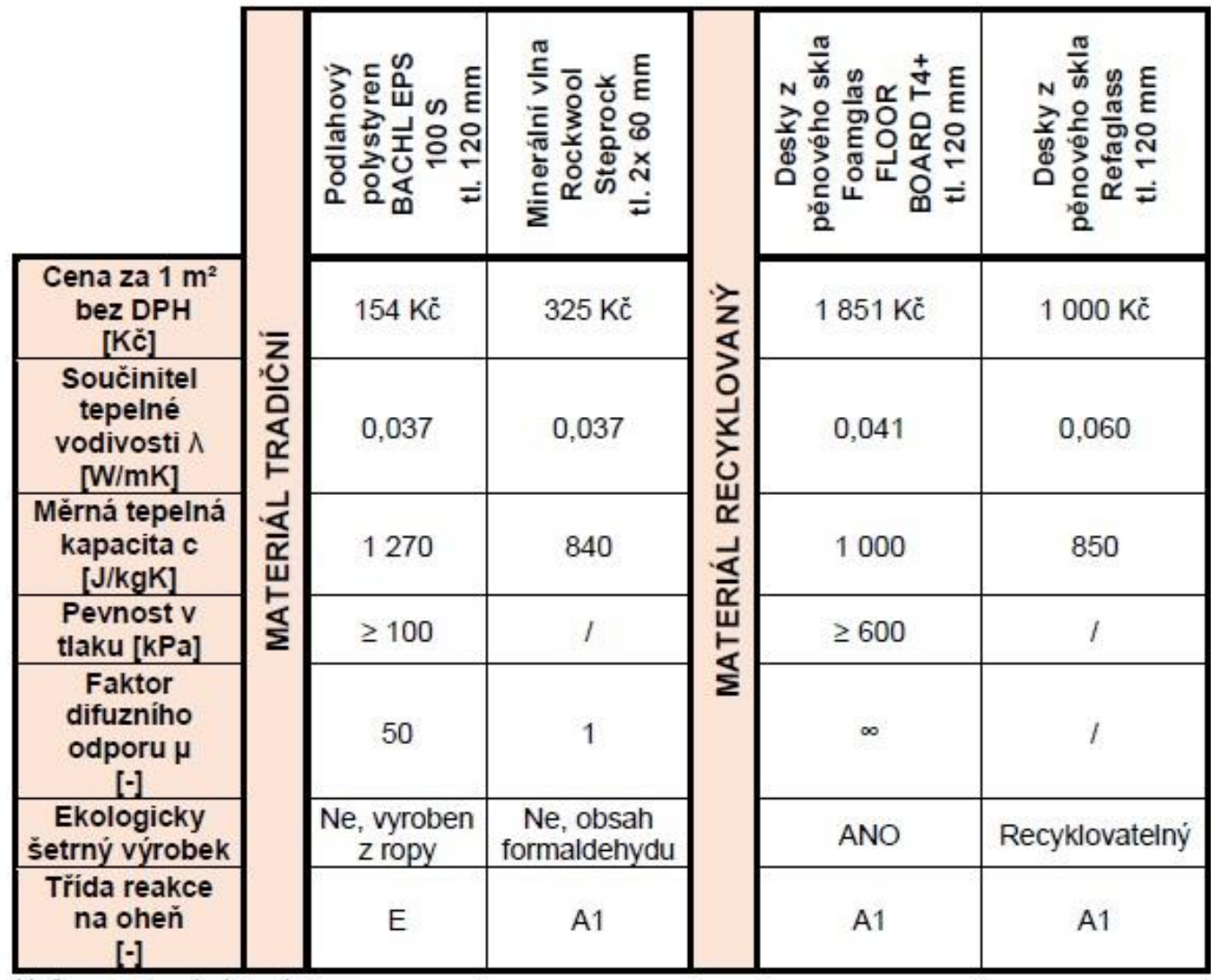

/ informace nebyly nalezeny

Zdroj: Vlastní tvorba

Obrázek č. 7 Porovnání zateplení fasády

\begin{tabular}{|c|c|c|c|c|c|c|c|c|}
\hline & \multirow{7}{*}{ 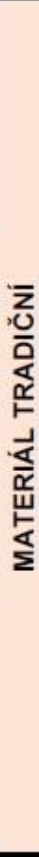 } & 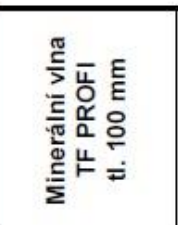 & 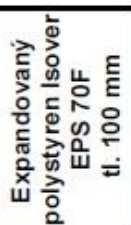 & \multirow{7}{*}{ 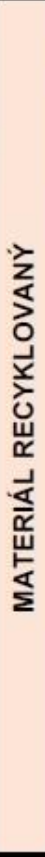 } & 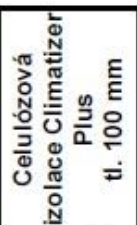 & 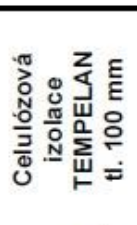 & 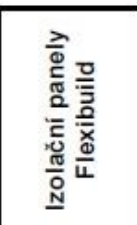 & 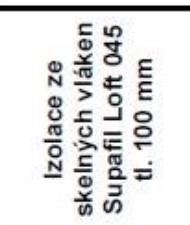 \\
\hline $\begin{array}{c}\text { Cena za } 1 \mathrm{~m}^{2} \\
\text { bez DPH } \\
{[K \mathrm{Kc}]}\end{array}$ & & $199 \mathrm{Kc}$ & $125 \mathrm{Kc \check {c }}$ & & $\begin{array}{c}163 \mathrm{Kč} \\
\text { vč. } \\
\text { zafoukání }\end{array}$ & $\begin{array}{c}164 \mathrm{KČC} \\
\text { vč. } \\
\text { zafoukání }\end{array}$ & I & $\begin{array}{c}120 \mathrm{Kč} \\
\text { vč. } \\
\text { zafoukání }\end{array}$ \\
\hline $\begin{array}{l}\text { Součinitel } \\
\text { tepelné } \\
\text { vodivosti } \wedge \\
\text { [W/mK] }\end{array}$ & & 0,036 & 0,039 & & $\begin{array}{c}0,035- \\
0,042\end{array}$ & $\begin{array}{l}0,037- \\
0,040\end{array}$ & 0,046 & $\begin{array}{l}0,034- \\
0,045\end{array}$ \\
\hline $\begin{array}{c}\text { Mèrná tepelná } \\
\text { kapacita c } \\
{[\mathrm{J} / \mathrm{kgK}]}\end{array}$ & & 800 & 1270 & & 1907 & 2000 & I & 840 \\
\hline $\begin{array}{c}\text { Faktor } \\
\text { difuzniho } \\
\text { odporu } \mu \\
{[-]}\end{array}$ & & 1 & $20-40$ & & $1,1-3$ & 1,5 & 202 & 1 \\
\hline $\begin{array}{c}\text { Ekologicky } \\
\text { šetrný } \\
\text { výrobek }\end{array}$ & & $\begin{array}{c}\mathrm{Ne} \text {, obsah } \\
\text { formaldehydu }\end{array}$ & $\begin{array}{c}\mathrm{Ne}, \\
\text { vyroben } \\
\mathrm{Z} \text { ropy }\end{array}$ & & ANO & ANO & $\begin{array}{c}\mathrm{Ne}, \\
\text { polystyren } \\
\text { vyroben z } \\
\text { ropy }\end{array}$ & Recyklovatelná \\
\hline $\begin{array}{c}\text { Třida reakce } \\
\text { na oheñ } \\
{[-]}\end{array}$ & & A1 & $\mathrm{E}$ & & c & B & I & A1 \\
\hline
\end{tabular}

/ informace nebyly nalezeny

Zdroj: Vlastní tvorba 
Porovnání tepelných izolací ukázalo následující výhody a nevýhody foukané tepelné izolace z celulózy:

Výhody:

- Cena

- Lepší tepelně izolační vlastnosti

- Ekologicky šetrný materiál

- Nevznikají odřezky při aplikaci

Nevýhody:

- Přispívá ke vzniku požáru

- Nutnost využití pomocných konstrukcí při zateplování např. obvodových stěn u zděných staveb

Při tomto porovnání byly také zjištěny výhody a nevýhody foukané izolace z recyklovaného skla:

Výhody:

- Lepší tepelně izolační vlastnosti

- Ekologicky šetrný materiál

- Nehořlavé

- Nevznikají placené odřezky při aplikaci

Nevýhody:

- Nutnost využití pomocných konstrukcí při zateplování např. obvodových stěn u zděných staveb

Dalším porovnávaným materiálem byla recyklovaná džínovina ULTRATOUCH. Výhody a nevýhody jejího využití jsou následující:

Výhody:

- Ekologicky šetrný materiál

- Nehořlavé

Nevýhody:

- Cena

- Nedostupnost na českém trhu

Posledním porovnávaným materiálem mezi tepelnými izolacemi byly desky z pěnového skla. Byly zjištěny tyto výhody a nevýhody desek z pěnového skla:

Výhody:

- Cena

- Ekologicky šetrný materiál

- Nehořlavé

- Vysoká pevnost v tlaku

Nevýhody:

- Horší tepelně izolační vlastnosti 


\section{Deskové materiály}

U deskových materiálů byly k porovnávání vybrány materiály využívané při provádění podhledů či používané při výstavbě příček a předstěn. Jako tradiční materiály byly zvoleny sádrokarton, OSB desky a dřevěné palubky. $Z$ recyklovaných materiálů byly porovnávány desky $z$ tetrapaku a sádrovláknité desky.

Obrázek č. 8 Porovnání deskových materiálů

\begin{tabular}{|c|c|c|c|c|c|c|c|c|}
\hline & \multirow{7}{*}{ 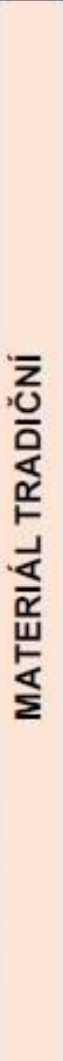 } & 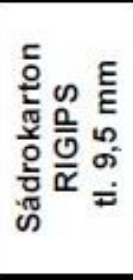 & 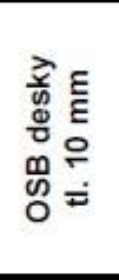 & 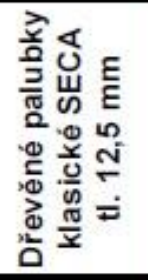 & \multirow{7}{*}{ 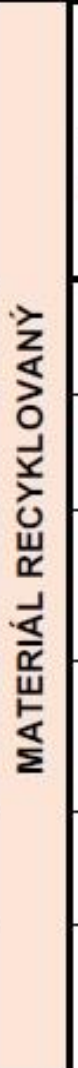 } & 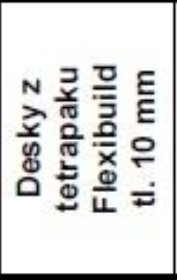 & 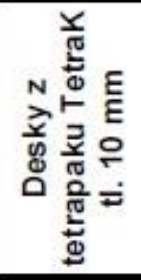 & 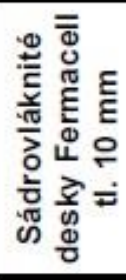 \\
\hline $\begin{array}{c}\text { Cena za } 1 \\
\mathrm{~m}^{2} \text { bez DPH } \\
\text { [Kč] }\end{array}$ & & $43 \mathrm{Kc \check {c }}$ & $83 \mathrm{Kc̆}$ & 149 Kč & & 1 & 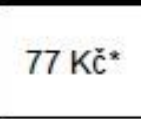 & $130 \mathrm{Kc \check {c }}$ \\
\hline $\begin{array}{l}\text { Objemová } \\
\text { hmotnost } \\
{\left[\mathrm{kg} / \mathrm{m}^{2}\right]}\end{array}$ & & 750 & 600 & 400 & & 743 & 1 & 1100 \\
\hline $\begin{array}{l}\text { Součinitel } \\
\text { tepelné } \\
\text { vodivosti } \Lambda \\
\text { [W/mK] }\end{array}$ & & 0,210 & 0,100 & 0,150 & & 0,180 & 0,146 & 0,320 \\
\hline $\begin{array}{c}\text { Faktor } \\
\text { difuzniho } \\
\text { odporu } \mu \\
{[-]}\end{array}$ & & 8 & 150 & 4,5 & & 1 & 136 & 13 \\
\hline $\begin{array}{c}\text { Ekologicky } \\
\text { šetrný } \\
\text { výrobek }\end{array}$ & & I & 1 & I & & ANO & ANO & ANO \\
\hline $\begin{array}{l}\text { Třída } \\
\text { reakce na } \\
\text { oheň } \\
{[-]}\end{array}$ & & A2 & D & D & & $E$ & C-D & A2 \\
\hline
\end{tabular}

Zdroj: Vlastní tvorba

Výsledkem srovnání těchto materiálů je zjištění těchto výhod a nevýhod recyklovaných deskových materiálů:

Výhody:

- Cena desek z tetrapaku oproti ceně za OSB desky

- Ekologicky šetrný materiál

- Únosnost sádrovláknitých desek oproti sádrokartonu

Nevýhody:

- Cena sádrovláknitých desek a desek z tetrapaku oproti sádrokartonu

- Horší tepelně izolační vlastnosti

- Dostupnost desek z tetrapaku na českém trhu 


\section{Střešní krytina}

U střešních krytin byly porovnávány tradiční materiály jako betonová střešní krytina, keramická střešní krytina, př́rodní břidlice a asfaltový šindel se střešními krytinami vyrobenými z recyklovaného plastu.

Obrázek č. 8 Porovnání deskových materiálů

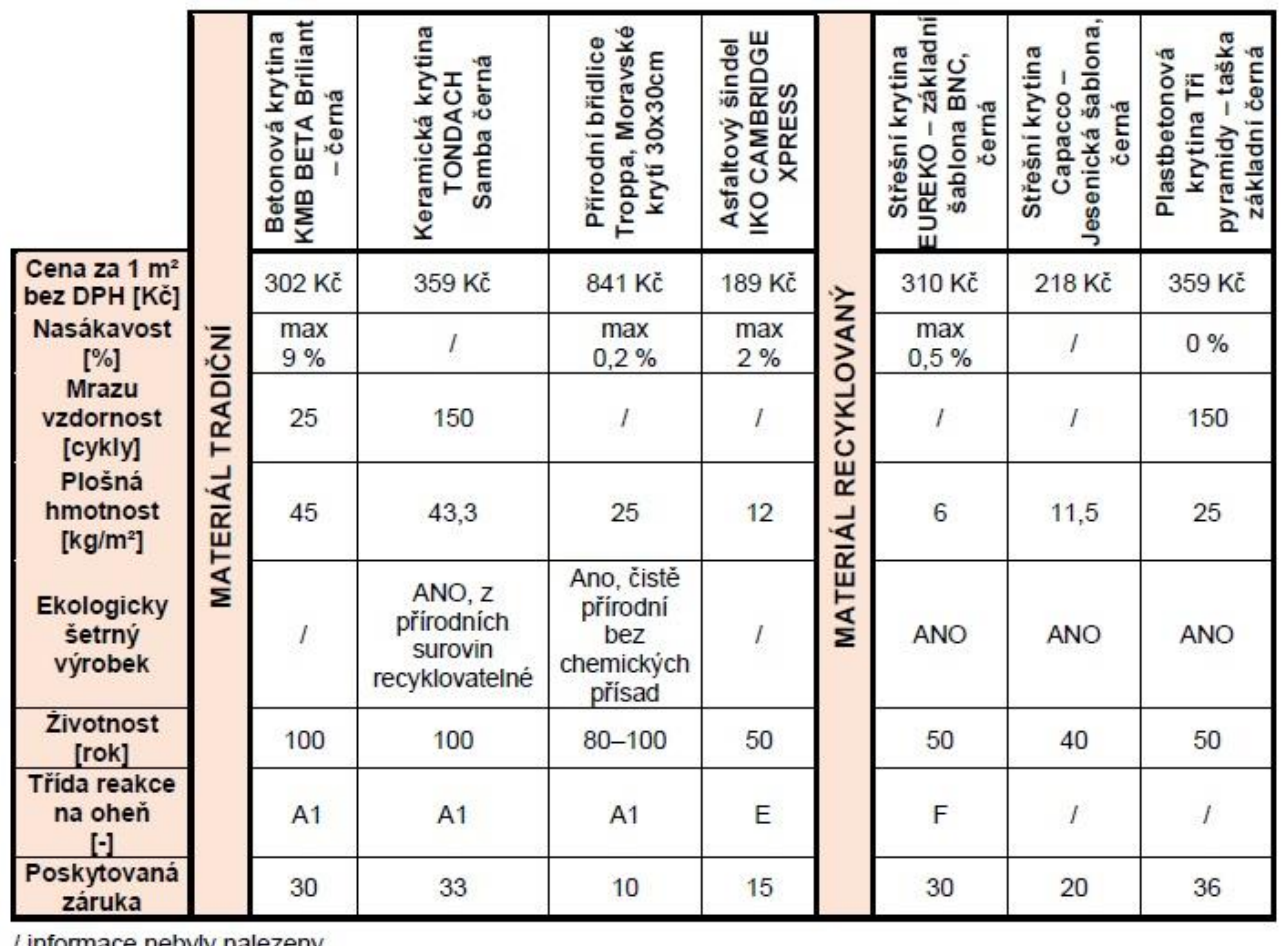

informace nebyly nalezeny

Zdroj: Vlastní tvorba

Po provedení tohoto porovnání byly zjištěny tyto výhody a nevýhody střešních krytin z recyklovaného plastu:

Výhody:

- Nízká hmotnost

- Nízká nasákavost

- Podobný vzhled

- Nerozbitnost

Nevýhody:

- Nižší životnost

- Tř́da reakce na oheň $F$

\section{Závěr}

Porovnání recyklovaných a tradičních materiálů používaných při různých fázích výstavby ukázalo, že jsou recyklované stavební materiály nejen konkurenceschopné, ale dokonce $v$ některých vlastnostech i lepší. Je důležité si však uvědomit, že materiál plní svoji funkci s ohledem na konstrukci, do které je určen. Stavební materiály jsou do konstrukce navrhovány tak, aby jako celek plnily svoji funkci nejlépe, jak mohou. 
Při porovnání podsypů pod základové konstrukce pěnové sklo disponuje lepšími tepelně izolačními vlastnostmi, nenasákavostí a vysokou pevností. Jeho velkou nevýhodou je však až dvacetinásobná cena za jednu tunu oproti ceně za štěrkový podsyp.

V obvodových konstrukcích není zatím rovnocenná náhrada za keramické či betonové tvárnice. Jedinou možnost nabízejí cihlobetonové tvárnice, které ale musí být použity současně s kontaktním zateplovacím systémem. Další možností použití recyklovaných materiálů v obvodových konstrukcích je využití panelů z tetrapaku. Tyto panely vynikají nízkou pořizovací cenou, rychlostí výstavby i lepšími tepelně izolačními vlastnostmi. Nevýhodou těchto panelů je nižší odolnost vůči mechanickému poškození a vůči požáru. Životnost je srovnatelná s betonovými tvárnicemi.

Největší rozmanitost ve využití recyklovaných materiálů nabízejí tepelné izolace. Foukané tepelné izolace z celulózy či skelných vláken jsou ekologicky šetrné, jejich předností je cena, výborné tepelně izolační vlastnosti a jejich aplikace bez zbytečného odpadu. Nevýhodou foukaných izolací je naopak nutnost použití pomocné konstrukce při zateplování, např́ílad obvodových zdí. Izolace z celulózy má také oproti ostatním izolačním materiálům horší odolnost proti požáru. Dalším porovnávaným materiálem byla recyklovaná džínovina. Recyklovaná džínovina nevyniká svými vlastnostmi nad tradičními materiály. Naopak její nevýhodou je jak vysoká cena, tak i prozatímní nedostupnost na českém trhu. Následovalo porovnání desek z pěnového skla. Jako největší výhoda se ukázala vysoká pevnost v tlaku, což dokazuje možnost využití izolace u pochozích a pojízdných střech. Nevýhodou izolace jsou horší tepelně izolační vlastnosti a až desetinásobná cena oproti tradičním izolacím.

U deskových materiálů je možnost nahrazení tradičních materiálů sádrovláknitými deskami a deskami z tetrapaku. Mezi výhody těchto desek patří jejich ekologická šetrnost. Sádrovláknité desky vynikají vysokou únosností oproti sádrokartonu. Desky z tetrapaku jsou zase cenově příznivější než OSB desky. Naopak cena sádrovláknitých desek je vyšší než u tradičních materiálů. Nevýhodou recyklovaných deskových materiálů jsou jejich horší tepelně izolační vlastnosti.

Střešní krytiny z recyklovaného plastu se vzhledově př́liš neliší od tradičních, jsou cenově srovnatelné, $v$ některých prípadech i cenově dostupnější. Mezi další přednosti těchto střešních krytin patří nízká hmotnost, nízká nasákavost a jejich nerozbitnost. Jedinou nevýhodou je nižší životnost, která je u výrobců uvedená jen poloviční oproti keramickým a betonovým střešním krytinám.

\section{References}

[1] Enviweb - zpravodajství životního prostředí, www.Enviweb.cz, online at: http://www.enviweb.cz/katalog/?id=749.

[2] Návrh domu z hlediska trvale udržitelný výstavby. Stavskola.cz [online]. Dostupné z: http://1url.cz/RtsYa

[3] KOLÁŘ, L. a KUŽEL, S. Odpadové hospodářství. České Budějovice: Jihočeská univerzita, 2000. ISBN 80-7040449-3.

[4] LCA - posuzování životního cyklu, www.lca.cz, online at: $\underline{\text { http://lca.cz/cs/domov/ }}$

[5] KURAŠ, M. Odpady a jejich zpracování. Vyd. 1. Chrudim: Vodní zdroje Ekomonitor, 2014, s. 146-154. ISBN 808-68-3280-5.

[6] SVOBODA, K. Stavební a demoliční odpad. Odpadové forum. CEMC, 2005, 05(2005), 8-19. ISSN 212-7779.

[7] Recycling ...: možnosti a perspektivy recyklace stavebních odpadů jako zdroje plnohodnotných surovin : sborník přednášek ... ročníku konference [online]. V Brně: Vysoké učení technické, Fakulta strojního inženýrství, 1996. ISBN 80-214-3142-3. Dostupné z: http://www.arsm.cz/dokumenty.php

[8] Třídění odpadu, www.trideniodpadu.cz, online at: https://www.trideniodpadu.cz/jak-se-recykluje-stavebniodpad

[9] SVOBODA, L. Stavební hmoty [online]. 3.vyd elektronické. Praha, 2013. ISBN 978-80-260-4972-2. Dostupné také z: http://people.fsv.cvut.cz/ svobodal/sh/SH3v1.pdf

[10] JURAJ, Kizlink. Odpady: sběr, zpracování, zužitkování, zneškodnění, legislativa. 3., upr. a rozš. vyd., V Akademickém nakl. CERM 1. vyd. Brno: Akademické nakladatelství CERM, 2014, s. 224, 323-326. ISBN 97880-7204-884-7. 
[11] Džínovina. Stavba-a-rekonstrukce.bydleniprokazdeho.cz [online]. b.r. Dostupné z: http://stavba-arekonstrukce.bydleniprokazdeho.cz/zateplovani-a-izolace/izolace-z-prirodnich-materialu.php

[12] REMEŠ, M. Možnosti aplikace recyklovatelných materiálů ve stavebnictví 1. Bydlení.cz [online]. 2008. Dostupné z: https://www.bydleni.cz/clanek/Moznosti-aplikace-recyklovatelnych-materialu-ve-stavebnictvi1

[13] CHYBík, J. Př́rodní stavební materiály. 1. vyd. Praha: Grada, 2009, s. 21-23. Stavitel. ISBN 978-80-247-25321.

[14] HEJHÁLEK, J. Difúze vodní páry - veličiny, hodnoty a jednotky. Stavebnictví3000.cz [online]. 2010. Dostupné z: http://www.stavebnictvi3000.cz/clanky/difuze-vodni-pary-veliciny-hodnoty-a-jednotky/

[15] Ekologicky šetrný materiál. Wienerberger.cz [online]. b.r. Dostupné z: http://wienerberger.cz/fakta/ekologick\%C3\%A9-a-p\%C5\%99\%C3\%ADrodn\%C3\%AD-materi\%C3\%A1ly

[16] Životnost materiálu. Technologie.fsv.cvut.cz [online]. b.r. Dostupné z: http://technologie.fsv.cvut.cz/122ytrh/get.php?id=148

[17] Marzouk, M., Azab. S., Environmental and economic impact assessment of construction and demolition waste disposal using system dynamics, (2014) Resources, Conservation and Recycling, 82, pp. 41-49. https://doi.org/10.1016/j.resconrec.2013.10.015

[18] Baldwin, A., Poon, C.-S., Shen, L.-Y., Austin, S., Wong, I. Designing out waste in high-rise residential buildings: Analysis of precasting methods and traditional construction

[19] Liu, Z.; Osmani, M.; Demian, P.; Baldwin, A.; A BIM-aided construction waste minimisation framework

[20] Guinée, J.; Life cycle sustainability assessment: What is it and what are its challenges?, Taking Stock of Industrial Ecology, 1 January 2015, Pages 45-68

[21] Finkbeiner, M.,Schau, E.M., Lehmann, A., Traverso, M., Towards life cycle sustainability assessment, Volume 2, Issue 10, 2010, Pages 3309-3322. doi:10.3390/su2103309 